\title{
Studies on shelf-life of fresh soymilk
}

\author{
- SMita U. KHODKE ${ }^{1}$ KIRAN S. SHINDE ${ }^{1}$ and GOVIND B. YenGE*
}

Department of Agricultural Process Engineering, Mahatma Phule Krishi Vidyapeeth, Rahuri, AHMEDNAGAR (M.S.) INDIA ${ }^{1}$ Department of Agricultural Process Engineering, Vasantrao Naik Marathwada Krishi Vidyapeeth, PARBHANI (M.S.) INDIA (Email: kiranss1989@gmail.com)

\section{SUMMARY :}

Fresh soymilk was inspected for quality attributes like viscosity, TSS, titrable acidity, $\mathrm{pH}$, standard plate count, yeast and mould count daily for sample stored in refrigerated condition and at the regular interval of $4 \mathrm{hrs}$ for sample stored in ambient condition. On the basis of the quality attributes, it was observed that fresh soymilk samples were acceptable upto 5 days in refrigerated condition while same samples were acceptable upto $16 \mathrm{hrs}$ in ambient temperature condition from the day of preparation. Thus, the study reveals that, fresh soymilk sample stored at refrigerated condition has better shelf-life.

KEY WORDS : Soymilk, Refrigeration, Storage, Shelf life

How to cite this paper : Khodke, Smita U., Shinde, Kiran S. and Yenge, Govind B. (2014). Studies on shelf-life of fresh soymilk. Internat. J. Proc. \& Post Harvest Technol., 5 (2) : 120-126. 